\title{
The (un)speaking self: an identity-based model for employee voice and silence
}

BRUNO FELIX ${ }^{1}$

${ }^{1}$ Fucape Business School / Programa de Pós-Graduação em AdMinistração, Vitória - ES, BraziL

\begin{abstract}
The literature on employee voice and silence has typically explored these behaviors as being motivated by calculative-instrumental purposes (what will I gain/lose if I volunteer information?). I argue that voice and silence are social-functional behaviors that are embedded within everyday interactions at work, and I draw on social identity theory to propose an identity-based model of employee voice and silence (how does speaking up affect my definition of who I am?). The presented model explains how individuals can volunteer information or remain silent by preserving or restructuring their sense of self in the face of identity threats. I also explore the conditions for each identity-based speaking behavior and offer contributions to both the Organizational Behavior and Industrial Relations literature on employee voice and silence.
\end{abstract}

Keywords: Voice. Silence. Identity. Threat. Self.

\section{O self que (não) fala: um modelo baseado em identidades sobre voz e silêncio de empregados}

\section{Resumo}

A literatura sobre voz e silêncio de empregados tem apresentado tais comportamentos como motivados por propósitos calculativosinstrumentais (o que eu ganharei/perderei se eu falar?). Eu defendo que voz e silêncio são comportamentos sociofuncionais inseridos em interações do cotidiano no trabalho e me fundamento na teoria da identidade social para propor um modelo baseado em identidades sobre a voz e silêncio de empregados (como falar afeta minha definição de quem sou?). O modelo apresentado explica como indivíduos podem falar ou se manter em silêncio ao preservar ou reestruturar seu senso de self diante de ameaças a identidades. Eu também exploro as condições para cada comportamento de voz baseado em identidades e apresento contribuições para as literaturas sobre voz e silêncio nos campos do Comportamento Organizacional e das Relações Industriais.

Palavras-chave: Voz. Silêncio. Identidade. Ameaça. Self.

\section{El self que (no) habla: un modelo basado en la identidad de la voz y el silencio de los empleados}

\section{Resumen}

La literatura sobre la voz y el silencio de los empleados ha presentado un comportamiento motivado por propósitos instrumentales calculadores (¿qué ganaré/perderé si hablo?). Sostengo que la voz y el silencio son comportamientos sociofuncionales integrados a las interacciones cotidianas en el trabajo, y me fundamento en la teoría de la identidad social para proponer un modelo basado en la identidad de la voz y el silencio de los empleados (¿cómo afecta el habla a mi definición de quién soy?). El modelo presentado explica cómo las personas pueden hablar o permanecer en silencio mientras preservan o reestructuran su sentido de identidad frente a amenazas a las identidades. También exploro las condiciones para cada comportamiento de voz basado en la identidad y presento contribuciones a la literatura sobre voz y silencio en los campos de comportamiento organizacional y relaciones industriales.

Palabras clave: Voz. Silencio. Identidad. Amenaza. Self. 


\section{INTRODUCTION}

Contemporary organizations are often challenged to respond quickly and adequately to complex and changing scenarios (BUDD, 2014). In this context, developing a workforce that shares information and ideas fluidly constitutes an important source of organizational competitive advantages (WILKINSON and FAY, 2011). Improving this flow of idea sharing allows companies to better respond to environmental demands, adjust to contingency forces and make better decisions (FRAZIER and FAINSCHMIDT, 2012). Additionally, it is important to develop workplaces where employees can feel comfortable expressing their dissatisfaction with injustices at work (PINDER and HARLOS, 2001). Thus, it is not surprising that practitioners and scholars have been increasing their interest in understanding the factors that promote and inhibit employees' willingness to volunteer information at work (MORRISON, 2011; VAN DYNE, ANG and BOTERO, 2003).

However, speaking up at work is not a risk-free action (DETERT and EDMONDSON, 2011). For this reason, a significant portion of both the Organizational Behavior (OB) and Industrial Relations (IR) literature on employee voice and silence has adopted an instrumental/calculative approach for understanding this phenomenon (e.g., DETERT and BURRIS, 2007; DETERT and TREVIÑO, 2010; LEPINE and VAN DYNE, 2001; MORRISON, 2011) because expression is a two-edged sword. On one side, employees may have an interest in improving organizational, group and individual gains through participation and engagement (CHAMBERLIN, NEWTON and LEPINE, 2018; MORRISON, 2011), while on the other side, people may question whether additional effort and action will be rewarded and will evaluate the risks of dissatisfying other individuals' or groups' interests and expectations through the expression of their ideas (BURRIS, DETERT and CHIABURU, 2008). Therefore, it is reasonable that the decision of speaking up at work is often portrayed as a risk-return calculative and instrumental decision.

This study adopts a different perspective for exploring employee voice and silence by exploring the role of individual identities in terms of whether and how employees volunteer information or decide to withdraw relevant information at work. Although I recognize the relevance and plausibility of the calculative-instrumental approach, I argue that employee voice and silence are only partially explained by this lens (KLAAS, OLSON-BUCHANAN and WARD, 2012). I propose that aside from asking themselves what they will gain and lose from expressing their voices at work, employees also intuitively question how speaking up can affect their sense of self-worth in conflict-filled day-to-day situations (ASHFORD and BARTON, 2007). I argue that employee voice and silence are also socially motivated behaviors that can both function as identity-preserving or identity-restructuring strategies within the context of workplace relationships (PETRIGLIERI, 2011).

Thus, in this study, I aimed to develop an identity-based model of employee voice and silence. In the presented model, voice and silence are embedded in ongoing work relationships (LAM, REES, LEVESQUE et al., 2018) and are anticipatory coping responses that employees adopt to manage identity threats related to the possible act of voicing relevant ideas. The literature on voice and silence at work can benefit from the adoption of this identity-centered approach, especially because it allows us to analyze the decision to (not) volunteer information at work in light of an underexplored voice/silence motive: the sense of self-worth of individuals (SLUSS and ASHFORTH, 2007). Thus, this study fills an important gap in the literature on employee voice and silence by including the identity lens among other already extensively explored determinants of voice (KAUFMAN, 2015; KLAAS, OLSON-BUCHANAN and WARD, 2012; MORRISON, 2011).

\section{LITERATURE REVIEW}

\section{Employee voice and silence: an overview}

Employe voice and silence are defined in the literature in two main distinct ways, although there is a consensus that voice refers to an 'opportunity to have a say', while silence is the opposite (MOWBRAY, WILKINSON and TSE, 2014). In the context of the Industrial Relations (IR) and the Organizational Behavior (OB) literatures such concepts ate interpreted distinctively. In the IR literature the act of voicing up is built in the level of organizational systems, and it refers to raising dissatisfactions with an intent to protect employee's needs (KAUFMAN, 2015). This form of voice tends to be formal, and pro-social (KLAAS, OLSON-BUCHANAN and WARD, 2012). In turn, the OB literature sees voice as an individual decision of expressing ideas for the benefit of the organization (MORRISON, 2011). Conversely, in the IR literature, voice is interpreted as the act not expressing pro-social issues formally that could protect employee's interests (FELIX, MELLO and VON BORELL, 
2018). The OB literature, in turn sees silence of an individual decision of withholding relevant information that could help organizations to improve their performances (KAUFMAN, 2015). In this sense, voice tends to be more informal and focus on improving organizational or unit functioning (LAM, REES, LEVESQUE et al., 2018). In this study I adopt an OB perspective for voice and silence, which is explained in more detail in the next section. Table 1 (MOWBRAY, WILKINSON and TSE, 2014, p. 4) summarizes such differences.

Table 1

Comparing IR and OB conceptualization of employee voice

\begin{tabular}{|c|c|c|}
\hline Concept & $\begin{array}{c}\text { Human resources management/ } \\
\text { industrial relations }\end{array}$ & Organizational Behavior \\
\hline Form & System & Bahaviour \\
\hline Motive & $\begin{array}{l}\text { Dissatisfaction } \\
\text { Pro-social }\end{array}$ & $\begin{array}{l}\text { Pro-social } \\
\text { Justice } \\
\text { Dissatisfaction }\end{array}$ \\
\hline Expectation & $\begin{array}{l}\text { In-role } \\
\text { Extra-role }\end{array}$ & $\begin{array}{l}\text { Extra-role } \\
\text { In-role }\end{array}$ \\
\hline Beneficiary & $\begin{array}{l}\text { Employee } \\
\text { Organization }\end{array}$ & Organization \\
\hline Mechanism & Formal & Informal \\
\hline Content and types & $\begin{array}{l}\text { Task-based participation } \\
\text { Upward problem-solving } \\
\text { Grievance procedures }\end{array}$ & $\begin{array}{l}\text { Suggestions for change and improvement } \\
\text { Expression of concern about work issues harmful to organization }\end{array}$ \\
\hline Focus & Participation in decision-making & $\begin{array}{l}\text { Communicating different points of view } \\
\text { Improve organizational or unit functioning }\end{array}$ \\
\hline
\end{tabular}

Source: Elaborated by the author.

\section{Employee voice and silence: this study}

Voice is defined here as a discretionary formal or informal communication of ideas, concerns, opinions or suggestions that can be performed with the intention to either improve organizational functioning and/or raise issues that are independent from the organizational interests (BURRIS, DETERT and CHIABURU, 2008; DETERT and TREVIÑO, 2010; TANGIRALA and RAMANUJAM, 2008). Although it is a discretionary behavior, voice does not occur in a vacuum; it occurs in the context of a broader system of beliefs, social positions and mechanisms that foster or inhibit its expression (FELIX, MELLO and VON BORELL, 2018). In turn, I define silence as the withholding of such communication and the refusal to share relevant information for the same purposes (BRINSFIELD, 2013; GREENBERG and EDWARDS, 2009; MORRISON and MILLIKEN, 2000; TANGIRALA and RAMANUJAM, 2008; WANG and HSIEH, 2013). In both cases, I refer to upward and horizontal communications. The content of what is (not) said might include different types of critical work-related information (TANGIRALA and RAMANUJAM, 2008), such as a situation involving misconduct (PINDER and HARLOS, 2001) or injustice (NG and FELDMAN, 2012), a dissenting opinion or a suggestion for improving organizational performance (DUTTON and ASHFORD, 1993).

The presented definitions of employee voice and silence portray the two as opposite behaviors, but there is controversy surrounding this issue in the literature. My understanding is in line with other studies (e.g., DONAGHEY, CULLINANE, DUNDON et al., 2011; MORRISON, 2011; MORRISON, WHEELER-SMITH and KAMDAR, 2011; TANGIRALA and RAMANUJAM, 2008), in which the decision to express potentially relevant information (voice) is the opposite of choosing to withhold it (silence), i.e., a high level of voice is associated with a low level of silence and vice versa (MORRISON, 2011). However, some scholars argue that while voice is a proactive choice, silence can be a default response or a habitual state; as such, they should be treated as separate constructs (BRINSFIELD, 2013; PINDER and HARLOS, 2001; VAN DYNE, ANG and BOTERO, 2003). Morrison (2011) suggested that most definitions of silence include the intentional withholding of information and 
not a passive failure to speak (HARVEY, MARTINKO and DOUGLAS, 2009; MORRISON and MILLIKEN, 2000; WANG and HSIEH, 2013). Thus, I view voice and silence as different sides of the same coin (ASHFORD, SUTCLIFFE and CHRISTIANSON, 2009; CULLINANE and DONAGHEY, 2014).

\section{Motivations for employees' voice and silence: what do we know so far?}

Because this article aims to present an identity-based model for voice and silence at work, it is important to review how the literature has explored the different motives that individuals have for such behaviors. A common assumption within the $O B$ and IR literature is that the driving motive for voice is to remove dissatisfaction by improving the organization. Because voicing one's thoughts is risky behavior, individuals consider the consequences of the decision to offer sensitive information. Thus, most studies that analyze the motives for employee voice and silence have adopted a calculativeinstrumental perspective (e.g., BURRIS, 2012; DETERT and BURRIS, 2007). However, other studies have also explored explanations other than calculative/instrumental explanations for these behaviors (ASHFORD and BARTON, 2007; DETERT and EDMONDSON, 2011).

Studies developed from the perspective of instrumental/calculative motives for employee voice and silence emphasize two main outcome-related issues (MORRISON, 2011). First, they focus on the individual's evaluations of the likelihood of the effectiveness of voicing one's thoughts (perceived efficacy of voice), which means that individuals ask themselves whether the target will listen and use the information provided to make the related changes or improvements (DETERT and BURRIS, 2007). When employees, in this process of evaluation, experi ence feelings of futility (PINDER and HARLOS, 2001) and interpret that speaking up will not result in being heard, they tend to adopt an "acquiescent silence" (KNOLL and VAN DICK, 2013; VAN DYNE, ANG and BOTERO, 2003). Such studies draw on assumptions from the classical theory of motivation from Vroom (1964), whereby efforts are related to expectancy beliefs.

Second, they emphasize the individual's evaluations of the likelihood of having negative outcomes related to the act of speaking up (perceived safety of voice), which suggests that employees question whether voicing their thoughts may generate retaliation and punishment, such as damaging their performance evaluation, or generate other career-related costs, such as being passed over for a promotion or being fired (WHITESIDE and BARCLAY, 2013). In this case, trust and fear are the driving forces that lead to voice and silence behaviors, and psychological safety is often portrayed as a mediator between voice behavior and its antecedents (CULLINANE and DONAGHEY, 2014).

I argue that the decision to speak and the manner of speaking up at work are influenced by less intentional psychological processes of individual identity management. To provide conceptual support for my argument, I next draw on the extant literature to explain how I define identity within this article, why events occurring when individuals question whether they should speak out are perceived as identity threats and what is known about how individuals respond to them.

\section{Social identity and employees' voice and silence}

\section{Defining identity}

The presented model is grounded on the idea that workplace interactions offer a stimulus for identity enactment (ASHFORTH, 2001; LEAVITT and SLUSS, 2015; FELIX and CAVAZOTTE, 2019) and that situations on everyday organizational life, including the choices for (not) speaking up, are navigated via the social self (HOGG and TERRY, 2000). Because there are many distinct approaches for the study of identity (PRATT and FOREMAN, 2000; GOMES and FELIX, 2019), I delineate what I mean by the word 'identity' within the context of this study. First, I focus on only individual (or self) identities; and do not explore identities that are held by a group or a collective in this article.

Second, identities are foundations of consistency in terms of how people think, act and feel about themselves. Identities function as implicit meaning structures that guide an individual's understanding of the world (BREWER and GARDNER, 1996; FELIX and CAVAZOTTE, 2019). They also serve to satisfy our need to see ourselves in a positive light (DUTTON, ROBERTS and BEDNAR, 2010). Self-identities help individuals achieve some level of emotional and cognitive stability that is necessary for interacting within work relationships (COOPER and THATCHER, 2010). 
Third, although identities offer stability to one's sense of self, such definitions are not particularly stable or homogeneous; individuals develop a pool of possible distinct selves and choose the specific identities that seem to generate more appropriate outcomes within the context of specific interactions that develop at work (CONROY and O'LEARY-KELLY, 2014). Thus, individual identities are malleable (see identity malleability; MARKUS and WURF, 1987; PETRIGLIERI, 2011; CONROY and O'LEARY-KELLY, 2014), have a multiplex and dynamic character and are constantly valued via social interactions. In this process, individuals confer different levels of importance to distinct identities. This property, named identity salience, refers to how central an identity is to the sense of self and suggests that individuals tend to make consistent choices when confronted with conflict situations (ASHFORTH, 2001).

Fourth, self-identities are susceptible to the influence of social proscriptions (see WEAVER and AGLE, 2002) because the self reflects society; the sense of self-worth is socially constructed (MEAD, 1934). Thus, because individuals reflect society (structure) and make choices (agency), it is possible to see that different individuals show distinct levels of internalization of relational and collective social proscriptions in the identities. For example, the collective aspect of the identity of a religious person may make them feel valued when they act honestly. Then, when confronted with an uncomfortable situation for expressing oneself, that person may have a stronger tendency to express their ideas (HOOD JUNIOR, SPILKA, HUNSBERGER et al., 1996).

In summary, individuals negotiate their identities within social interactions, and I argue that such identities are sustained or changed in social interactions through enacting behaviors within the organizational context, such as voice and silence. Speaking up or remaining silent about relevant issues at work can contribute to the reinforcement of the sense of self of an individual (ASHFORD and BARTON, 2007). However, in some situations in which an individual's behavior does not align with the expectation that significant others may have, it can also lead to potential harm to one's sense of self-worth. I then provide an explanation for this process, which is referred to as an identity threat (KREINER and SHEEP, 2009).

\section{Identity threats and coping responses}

Identity threats are "experiences appraised as indicating potential harm to the value, meanings and enactment of an identity" (PETRIGLIERI, 2011, p. 644). I argue that when an individual faces a situation in which the act of speaking up is interpreted as potentially harmful to his/her sense of self-worth, this individual faces an identity threat. For a better explanation of the chosen definition, I next clarify the two major aspects that are present in this definition.

The expression "experiences appraised as indicating potential harm" suggests that the locus of the identity threat is not the threatening individual(s) but the threatened individual. The individual's appraisal of a situation that can be interpreted as an identity threat plays a central role in this process (PETRIGLIERI, 2011); this implies, for example, that a leader's behavior in a meeting cannot itself be classified as an identity threat. To characterize a behavior as an identity threat, the individual to whom that behavior is directed needs to interpret the experience as a cue of potential harm to their identity (SMITH, 1991). Thus, individuals evaluate the meaning of a given event based on their well-being (PETRIGLIERI, 2011), decide how they will classify the event and then respond to it (SMITH, 1991). The fact that individuals appraise identity threats differently is often explained by the term identity threat sensitivity (or threat sensitivity), which refers to an individual's tendency to interpret conflict experiences as potentially harmful to the self (SLUSS and ASHFORTH, 2007), which means that the same experience might be interpreted as positive or neutral by one individual but as highly threatening by another (LEAVITT and SLUSS, 2015).

Having discussed the meaning of an identity threat, I conclude the literature review by exploring how individuals cope with identity threats. When individuals appraise an experience as harmful to their sense of self-worth, they tend to negate the threat with the adoption of anticipatory coping responses. These coping responses are cognitive and behavioral efforts that are intended to reduce the severity of harm to one's identity (SMITH, 1991). Petriglieri (2011) categorized two different types of anticipatory coping responses (or threat responses) based on their function: identitypreserving and identity-restructuring responses. Identity-preserving responses target the source of the potential harm and do not involve changes to the threatened identity. However, these coping responses are not always successful, and the individual may come to believe that an identity threat is unsolvable under the condition of the existing selfdefinition (LEAVITT and SLUSS, 2015). An alternative coping response in this case is the adoption of identity-restructuring 
responses, which target the transformation of an aspect of the threatened identity to reestablish thew stability of the self (ASHFORTH, 2001).

In this article, I integrate the micro-OB employee voice and silence and the identity literature to develop a model for exploring the self-related motives that drive the choice of to speak up or to remain silent at work. In the following section, I present the two questions that guided the construction of the model and oriented the logic of its presentation.

Question 1: How do employees use voice and silence as responses to voice-related identity threats at work?

Question 2: What are the conditions that influence how individuals respond to voice-related identity threats?

\section{An identity-based model of employee voice and silence}

Based on the review that I presented on the employee voice/silence and identity literature, I present the theoretical model in Figure 1, which is based on a set of propositions that explain how an individual's sense of self-worth can be a driving force regarding the decision to volunteer information at work. Such propositions are labeled P1 through P5b in the framework.

Figure 1

An identity-based model of employee voice and silence

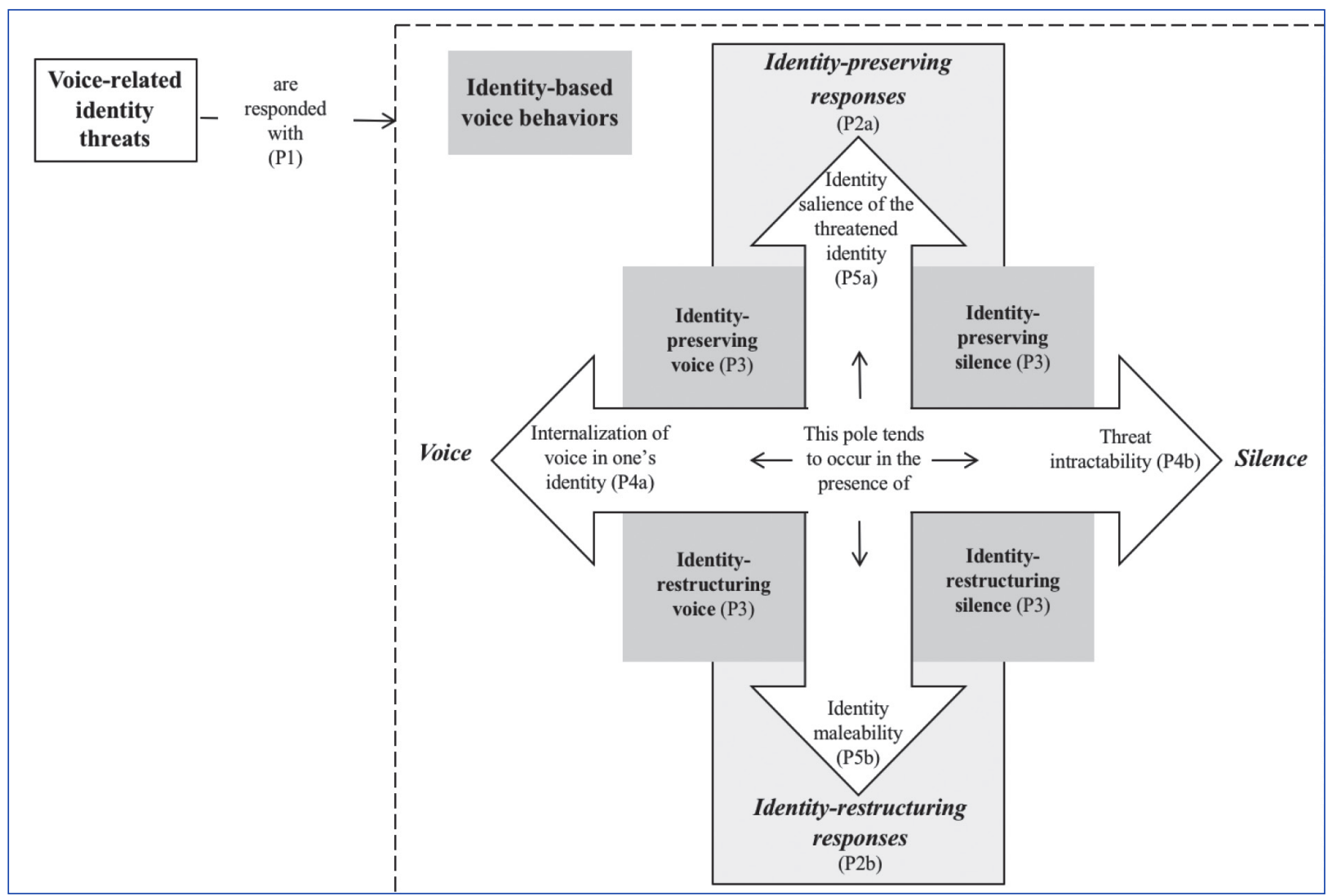

Source: Elaborated by the author. 


\section{Responses to identity threats}

To answer the first question (How do individuals use voice and silence as responses to voice-related identity threats at work?), I began by theorizing that when an employee feels doubtful about sharing a relevant idea at work, which I call voice conflict, such doubt can sometimes be driven by a worry about the impact of the decision to speak up on their self-worth. As stated by Ashford and Barton (2007), this decision mat not only be based on a rational and explicit evaluation of the perceived efficiency and the safety of voice, but also be a matter of preoccupation regarding the impact of the voice decision on one's self. When this happens, a voice-related identity threat, which is an intersubjective experience in which individuals question whether the act of voicing relevant information for organizational reasons may harm the value, meaning and enactment of their identities in the future, is established. Thus, this type of threat is distinct from that which is more commonly described in the voice literature, in that the focus of the doubt not only is cognitive but also has an emotional component. Although voice-related identity threats are a social phenomenon, their repercussions are self-centered.

When a voice-related identity threats is appraised by the employee as indicating potential harm to the individual's sense of self-worth, it can be classified as a form of identity threat. In this case, when questioning whether they should volunteer information, the individual evaluates a) whether their sense of self-worth will be devalued in the future (value), b) whether the association between the identity and its meanings will be possible in the future (meaning) and c) whether they will be able to enact the identity in further interactions (enactment). Thus, all the criteria suggested by Petriglieri (2011) to characterize an identity threat apply to such voice conflicts.

This theorizing is important because the presence of an identity-based component in a voice conflict influences how individuals will respond to it. The calculative/instrumental approach for voice conflicts suggests that voice responses, whether voiced or silence, are often strategic, intentional and focused on maximizing personal gains and minimizing losses, which is reasonable when the voice conflict is driven only by instrumental/calculative issues (DETERT and BURRIS, 2007). It is logical that the majority of voice and silence behaviors explored in the literature are strategic. However, when the voice conflict is driven by self-related issues, it is reasonable to suggest that they activate different types of voice and silence behaviors as responses (ASHFORD and BARTON, 2007). I call such responses identity-based voice behaviors.

Thus, I propose the following:

Proposition 1: Voice-related identity threats are responded to with identity-based voice responses rather than with instrumental/calculative voice responses.

I propose that identity-based voice responses are composed of two bipolar dimensions. The first dimension (see the vertical axe in Figure 1) is the type of response that employees will give. Because an identity-based voice conflict can be classified as an identity threat, I draw on the literature of coping responses to identity threats to answer this question.

I rely on Petriglieri's (2011) classification of anticipatory coping responses to identity threats to suggest two groups motives of possible threat responses based on their functions: identity-protection responses and identity-restructuring responses. While the former does not involve changes to the threatened identity, the latter requires a transformation in some threatened aspect of the self. Then:

Proposition 2: When individuals experience voice-related identity threats, they can adopt the following: P2a) identity-preserving responses, which involve no change to the employee's identity; or P2b) identityrestructuring responses, which involve the transformation of some aspect of the threatened identity.

Although identity-restructuring responses to voice-related identity threats could be intuitively associated with voice, an identity-preserving response could be more associated with silence. I theorize that both voice and silence are possible strategies for individuals who decide to preserve or restructure their identities. It is important to clarify that I understand voice as the act of vocalizing the relevant information in question. Thus, as individuals may not vocalize their issues, as illustrated in Figure 1, the poles that represent this dimension are voice and silence. This is in line with the previously explained position adopted in this article, in which I view voice and silence as opposite poles along a continuum (ASHFORD, SUTCLIFFE and CHRISTIANSON, 2009; CULLINANE and DONAGHEY, 2014; MORRISON, 2011). Although I understand that it 
is possible to consider the existence of 'speaking silently' or to 'to say without saying,' I adopt a verbal approach here for the use of the terms voice and silence.

Together, these two dimensions (types of coping responses on the vertical axis and voice decision on the horizontal axis) form four quadrants, each of which represents a motivation (preserve or restructure an identity) for the employee's choice of voice or silence responses.

- Identity-preserving voice refers to the act of voicing relevant information without transforming the employee's identity. This requires the ability to portray the presented idea as complementary to, not incompatible with, the aspect of the self that can be threatened by the act of voicing. Example: an employee who has a salient 'pro-management' identity wants to complain about an organizational practice that he sees as unfair to his colleagues. However, he understands that sharing this opinion openly will affect his sense of self-esteem, as it contradicts a valued identity. Thus, he tries to express his perception of unfairness by maintaining that, by correcting this practice, the organization will be able to achieve a better performance. Thus, the individual shares his perception under a structure of argumentation that aims to preserve his pro-management identity.

- Identity-restructuring voice refers to the act of voicing relevant information in such a way that there is a change in the employee's identity. In this form of voice, the individual assumes the risk of being devalued to rebuild his/ her identity. Here, speaking up is the act of voicing an idea, and it also involves the reconstruction of one's identity. Example: in the same situation presented previously, the individual decides to openly share his perception. He is aware that this self-exposure will threaten his 'pro-management' identity. In this case, the sense of self-esteem is promoted in the sense that some 'independent' employees will applaud this initiative, what may lead this individual to the construction of a new 'independent' salient identity.

- Identity-preserving silence refers to the act of withholding relevant information in such a way that preserves the threatened identity. In this case, the individual pretends that nothing is occurring and decides to assume the costs of the resulting inauthenticity. For example, in the same sample situation, the individual decides to not express his perception, thus preserving his 'pro-management' identity.

- Identity-restructuring silence refers to the act of withholding relevant information in such a manner that others may question whether the silence is caused by a change in the individual's identity. This response is a dramaturgical form of speaking by omission, with the objective of making others realize that there is something that needs to be said. For example, in this case, the previously presented employee would opt to not verbalize his opinion but with a different intention from that found in the identity-preserving silence. Here, the 'pro-management' individual intends to draw attention by omitting his opinion in a situation in which his social identity makes others expect him to speak in favor of the organizational point of view. However, through his silence, the individual breaks these expectations and generates speculation about the possibility that he is now adopting an 'independent' and critical perspective.

Thus, I suggest the following:

Proposition 3: Voice and silence are responses through which individuals can manifest their will to preserve or restructure an identity.

\section{Conditions influencing the responses to identity threats}

What are the conditions influencing the responses that individuals adopt for identity-based voice decisions? I draw on previous research of employee voice and silence and social identities to propose explanations about the identity-related characteristics that individuals may have in influencing their options for voice, silence and identity-preserving and restructuring responses to voice-related identity threats.

\section{Conditions for voice and silence}

I begin by exploring the option for voice. I suggest that individuals who internalize a proscription pro voice in their personality tend to use voice (either an identity-preserving or restructuring voice) as a response to voice-related identity threats. Personality traits (LEPINE and VAN DYNE, 2001) and cognitive style preferences (JANSSEN, DE VRIES and COZIJNSEN, 1998), for example, can influence the notion of voice behaviors as sources of personal distinctiveness. This evidence suggests 
that individuals with higher levels of extraversion and consciensciousness tend to see themselves positively when they adopt voice behaviors. A leader's behavior and personality can also influence an individual to volunteer information more often at work (DETERT and BURRIS, 2007). It is possible to suggest that individuals with highly salient relational identities emulate the behavior of their leader and then feed their selves by the act of speaking up at work. In turn, the collective level of the self can provoke an internalization of pro voice behaviors due to the influence of the organizational culture (DUTTON, ASHFORD, LAWRENCE et al., 2002), role perceptions (VAN DYNE, KAMDAR and JOIREMAN, 2008) and collective structures and mechanisms pro voice (MORRISON and MILLIKEN, 2000). I suggest that individuals with highly salient collective identities who may internalize a proscription pro voice when speaking up are characteristic of a prototypical member of the collective. Hence, I propose that:

Proposition 4a: The internalization of a proscription pro voice in one's personality increases the likelihood that employees will adopt voice as a response to voice-related identity threats.

Next, I analyze the conditions for the decision for silence. I theorize that silence is usually adopted when individuals interpret that speaking up will compromise their sense of self-worth. An identity-restructuring voice is sustainable only if the individual finds some affective support toward the emergent identity that is embedded in the content of what is said. When employees are unable to obtain such support, they tend to opt for silence. In other words, I maintain that the perception of threat intractability - the interpretation that an "identity threat is unresolvable under existing conditions" (LEAVITT and SLUSS, 2015, p. 597) - increases the likelihood of employee silence. Voice conflicts, when appraised as identity threats, generate psychological distress, which motivates individuals to try to eliminate such feelings through deliberate and iterative strategies (PETRIGLIERI, 2011). In such situations, individuals may, for example, imaginatively attempt to convince himself/herself that speaking up will not harm their sense of self-worth. The use of identity work, a coping strategy in which the individual "spins the identity" to resignificate it toward a more favorable interpretation aligned to their own specific sense of self, is an example of such a strategy (LEAVITT and SLUSS, 2015). However, due to the perception that such strategies of identity meaning management do not work and that speaking up will make the enactment of a salient identity unsustainable in the future, the voice-related identity threat is interpreted as intractable, and silence is chosen. I then theorize the following:

Proposition 4b: Threat intractability increases the likelihood that employees adopt silence in response to voice-related identity threats.

\section{Conditions for identity-preserving and restructuring responses}

I suggest that identity-preserving responses to voice-related identity threats (either identity-preserving voice or identitypreserving silence) are more likely to occur when the threatened identity is highly salient to the employee. The more central an identity is to one's sense of self, the less the individuals tends to risk the self-worth derived from that identity (ASHFORTH, 2001). Thus, if the aspect of the self that is under threat in the possible communication of a relevant idea at work is salient to an employee, they will likely avoid responses that expose them to rejection and disapproval. In this case, the employee chooses a coping response that does not involve changes to the threatened identity. I then propose the following:

Proposition 5a: The identity salience of the threatened identity increases the likelihood that an employee will adopt identity-preserving voice or silence as a response to voice-related identity threats.

In turn, I argue that identity-restructuring responses are more likely to occur in the presence of identity malleability. Identity-restructuring responses are based on an attempt, explicit or implicit, to remove the identity that is related to the socially desired self. This is possible only because identities are dynamic and multifaceted despite being reasonably stable (MARKUS and WURF, 1987; PETRIGLIERI, 2011). Thus, identities have the property of being malleable. However, individuals can show different degrees of malleability of their identities. Some employees may be more open to identity exits than others (LEAVITT and SLUSS, 2015), and I suggest that such openness to switching between identities that better promote 
the sense of self-worth increases the likelihood that identity-restructuring will be chosen as a response to voice-related identity threats. Thus:

Proposition 5b: Identity malleability increases the likelihood that employees will adopt identityrestructuring voice or silence as a response to voice-related identity threats.

In Figure 2, I present a summary of the conditions for each identity-based voice response based on Propositions 4a-5b, which provides a better understanding of the circumstances in which each response is more likely to occur.

Figure 2

Conditions that influence the responses to identity threats

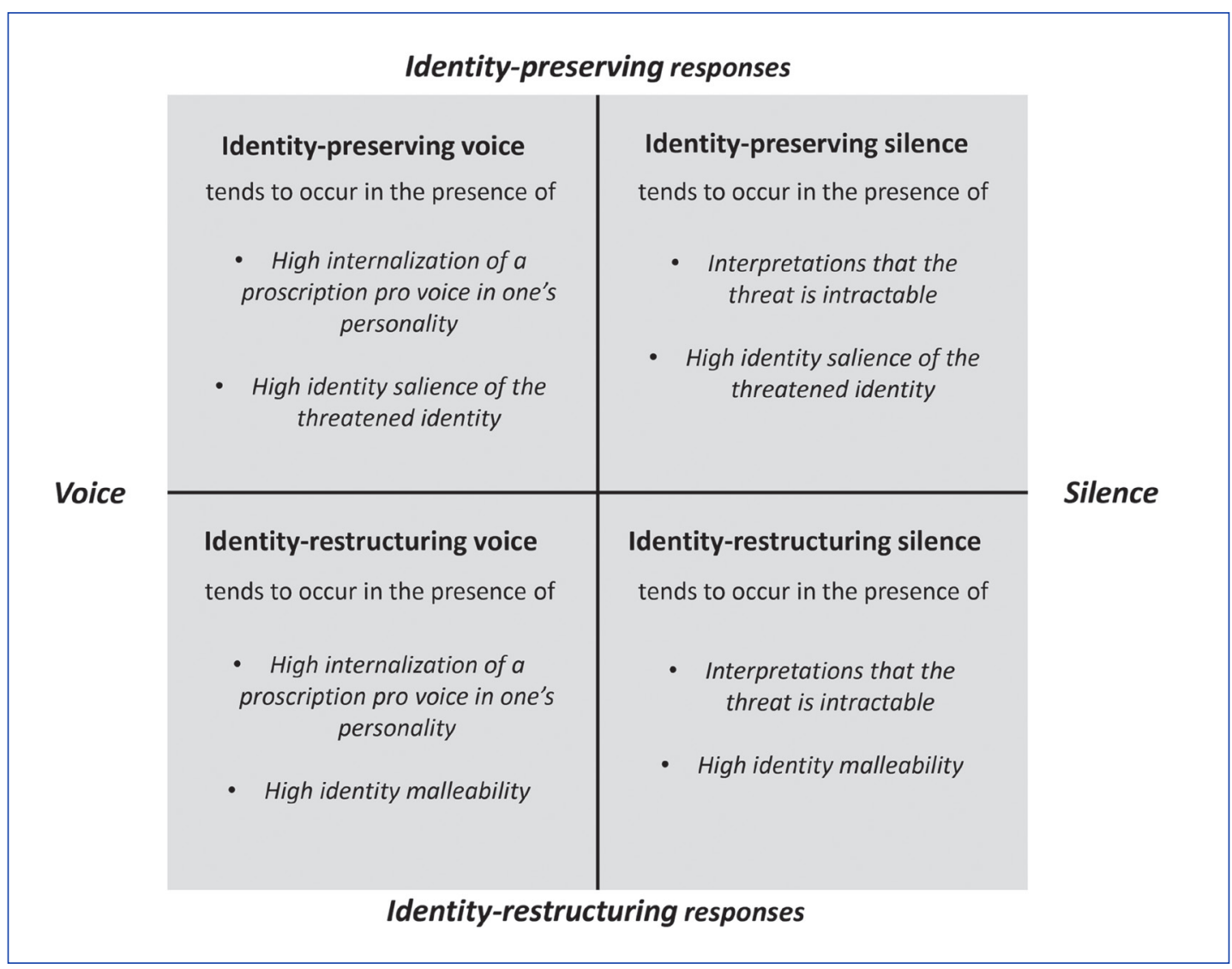

Source: Elaborated by the author.

Having presented the identity model of employee voice and silence, in the next section, I discuss the main contributions of this model to the literature, suggest directions for future research and present practical implications of the model for organizations and employees.

\section{Discussion}

Employee voice and silence, although widely explored constructs, are undertheorized in what is referred to as everyday workplace behaviors. I address this gap by theorizing that employee voice and silence are a) socio-functional behaviors that are embedded in workplace interactions; and b) responses to an identity threat that occurs when an individual questions whether voicing relevant information would harm the sense of self. Through the adoption of an identity lens, allowing us to connect individual actions and role-based social structures, this study contributes to the employee voice and silence literature by providing theoretical insights that could emerge only from an interdisciplinary perspective on motives for voice. This 
work answers the recent call for more integrative theoretical development of employee voice and silence (KLAAS, OLSONBUCHANAN and WARD, 2012).

The main contribution of this research to the $\mathrm{OB}$ voice literature is adding identity-based motives to the act of voicing or remaining silent at work. These motives are complementary to the calculative-instrumental approach that dominates the literature. This article extends the previous studies that proposed non-calculative approaches for employee voice, such as Ashford and Barton's (2007) study on the identity aspects of issue selling in organizations and Detert and Edmondson's (2011) study of implicit voice theories. The presented model shows an implicit and less intentional psychological process that aims to protect an individual's sense of self-worth while deciding whether to volunteer information. I introduced individual and contextual factors that influence how individuals appraise an identity-based voice conflict and the conditions that influence the coping strategies that individuals use to respond to them.

This study has implications for employees' personal dispositions to the act of speaking up or withdrawing relevant information at work. Although previous studies have suggested that individuals are responsive to environmental cues when evaluating the decision to share ideas and concerns (DUTTON, ASHFORD, LAWRENCE et al., 2002; STAMPER and VAN DYNE, 2001) regardless of the context, some individuals are more inclined to volunteer information than others (MORRISON, 2011). Factors such as individuals' feelings of efficacy (TANGIRALA and RAMANUJAM, 2008), personality and cognitive style preferences (JANSSEN, DE VRIES and COZIJNSEN, 1998) were shown to be antecedents of voice behaviors at work. However, I presented an unexplored individual antecedent of voice in this research: threat sensitivity, which is an individual's tendency to interpret conflict as potentially harmful to the self (SLUSS and ASHFORTH, 2007). I held that voice-related identity threats are responded to with identity-based voice responses. In other words, individuals who are more vulnerable in their sense of self-worth are more likely to adopt the four identity-based voice responses presented in this article. This is an important theoretical advancement to the literature on employee voice and silence that portrays these decisions as socio-functional behaviors that help individuals navigate socially in such a way that they can face conflict situations at work while seeing themselves in a positive light and promoting their personal distinctiveness.

This research also contributes to the IR literature on employee voice and silence. Micro-level studies on voice usually ignore the external context of organizations, which leads them to a susceptibility to ethnocentric bias because much of the explanatory power can derive from culture-dependent frames (KAUFMAN, 2015). Hoption, Christie, and Barling (2008) suggested that employee voice and silence must be theorized with the idea that organizations are open systems that influence and are influenced by what happens in the economic, legal and cultural environment. In the presented model, voice-related identity threats are not interpreted as phenomenon that originates from the threatening individual but from the threatened one. This means that although the behavior of others can stimulate or discourage voicing opinions, it is the individual with something to say that will see the situation as threatening (PETRIGLIERI, 2011). This judgment, however, can be strongly influenced by whether the economy is booming or in a recession, whether the law in a country promotes an employee's stability, whether organizations can easily terminate employees and whether the cultural system has a high or low power distance. In economies in a recession, where organizations can easily change from having permanent to temporary workers, and in cultures with high power distance, individuals will likely show higher threat sensitivity and would then be more likely to adopt identitybased voice responses.

\section{Future research}

This identity-based model of employee voice and silence offers initial answers about how an individual's sense of self can influence the decision to speak up or remain silent at work and also opens new avenues for exploring this issue in future studies. First, researchers may investigate the effects of the adoption of each of the four identity-based responses over time on an individual's sense of self. Identity work is an ongoing process (LEAVITT and SLUSS, 2015); as such, future longitudinal research could explore patterns of how identity-based voice or silence leads to other behaviors and the consequences of the recurrent adoption of one of the described tactics. It is possible that identity-restructuring voice decisions may demand additional behaviors when subsequent voice conflicts occur to protect or sustain the emerging identity that was revealed in its restructuring. It would also be interesting to elucidate the consequences of adopting identity-preserving voice for 
self-esteem because previous research has examined the negative outcomes produced by the feeling of inauthenticity generated by such strategies.

Second, studies could explore the influence of identity-based motives on individual characteristics that increase the likelihood that individuals will choose to speak up or not. For example, because previous research has suggested that extroverts assign higher importance to social attention (ASHTON, LEE and PAUNONEN, 2002), these individuals are probably more susceptible to voice-related identity threats. Additionally, there is evidence that individuals with high levels of agreeableness tend to adopt social approach behavior (LEIKAS and LINDEMAN, 2009) and identify identity threats in everyday interactions.

Third, although voice is intuitively associated with an identity-restructuring coping response to identity threats and because silence can be considered an identity- preserving response, this article proposes that individuals can restructure their identity through silence or preserve it through voice. Thus, these two counterintuitive forms of identity-based voice need further exploration so that we can better understand the tactics adopted by individuals when they want to speak silently or speak without harming the current self. It would be particularly relevant to explore the non-verbal communication of identityrestructuring silence and the semantic paradoxical structures of identity-preserving voice.

\section{Practical implications}

This research has implications for employees, leaders, organizations and unions. The presented model can help employees become more aware of their decisions regarding voice or silence at work as they frequently navigate voice-related identity threats. By recognizing the dynamics of voice/silence and identity- preserving/restructuring, employees can avoid unintentional and undesired patterns of coping responses. In turn, leaders may reflect on how their relationships may pressure their subordinates to behave in a specific way. For example, it is possible that leaders' excessive pressure for employee proactivity and self-sufficiency may silence subordinates who wish to express that the team needs more training but fear being labeled by the leader as too reactive or dependent on organizational support. Organizations and unions should also pay attention to the type of pressure they apply and whether these pressures represent threats to employee identities. If so, I recommend that organizations work on developing a collective image that is interpreted as pro-voice, which tends to increase the success of voice mechanisms. In turn, I suggest that unions work toward the development of a collective image that appears more attractive to individuals because the decision to engage in this form of voice can also be influenced by identity issues. This, however, would require deep reflection on the meaning that is institutionally attached to union voice in a broader sense. 


\section{REFERENCES}

ASHFORD, S. J.; BARTON, M. A. Identity-based issue selling. In: BARTEL, C. A.; BLADER, S.; WRZESNIEWSKI, A. (Eds.). Identity and The Modern Organization. New York: Psychology Press, 2007.

ASHFORD, S. J.; SUTCLIFFE, K. M.; CHRISTIANSON, M. K. Speaking up and speaking out: the leadership dynamics of voice in organizations. In: GREENBERG, J.; EDWARDS, M. S. (Eds.). Voice and Silence in Organizations. Bingley: Emerald, 2009.

ASHFORTH, B. Role transitions in organizational life: an identitybased perspective. London: Routledge, 2001.

ASHTON, M. C.; LEE, K.; PAUNONEN, S. V. What is the central feature of extraversion? Social attention versus reward sensitivity. Journal of Personality and Social Psychology, v. 83, n. 1, p. 245-252, 2002. Available at: <http://doi.org/10.1037/0022-3514.83.1.245>. Accessed on: Sept. 03, 2019.

BREWER, M. B.; GARDNER, W. Who is this "we"? Levels of collective identity and self representations. Journal of Personality and Social Psychology, v. 71. n. 1, p. 83-93, 1996. Available at: <http://doi. org/10.1037/0022-3514.71.1.83>. Accessed on: Sept. 03, 2019.

BRINSFIELD, C. T. Employee silence motives: investigation of dimensionality and development of measures. Journal of Organizational Behavior, v. 34, n. 5, p. 671-697, 2013. Available at: <http://doi. org/10.1002/job.1829>. Accessed on: Sept. 03, 2019.

BUDD, J. W. The future of employee voice. In: WILKINSON, A. et al. (Eds.). The handbook of research on employee voice: participation and involvement in the workplace. Cheltenham: Elgar Press, 2014.

BURRIS, E. R. The risks and rewards of speaking up: managerial responses to employee voice. Academy of Management Journal, v. 55, n. 4, p. 851-875, 2012. Available at: <http://doi.org/10.5465/ amj.2010.0562>. Accessed on: Sept. 03, 2019.

BURRIS, E. R.; DETERT, J. R.; CHIABURU, D. S. Quitting before leaving: the mediating effects of psychological attachment and detachment on voice. Journal of Applied Psychology, v. 93. n. 4, p. 912-922, 2008. Available at: <http://doi.org/10.1037/0021-9010.93.4.912>. Accessed on: Sept. 03, 2019.

CHAMBERLIN, M.; NEWTON, D. W.; LEPINE, J. A. A meta-analysis of empowerment and voice as transmitters of high-performance managerial practices to job performance. Journal of Organizational Behavior, v. 39, n. 10, p. 1296-1313, 2018. Available at: <http://doi. org/10.1002/job.2295>. Accessed on: Sept. 03, 2019.

CHIU, C. Y.; HONG, Y. Y.; DWECK, C. S. Lay dispositionism and implicit theories of personality. Journal of Personality and Social Psychology, v. 73, n. 1, p. 19-30, 1997. Available at: <http://doi.org/10.1037/00223514.73.1.19>. Accessed on: Sept. 03, 2019.

CONROY, S. A.; O'LEARY-KELLY, A. M. Letting go and moving on: workrelated identity loss and recovery. Academy of Management Review, v. 39, n. 1, p. 67-87, 2014. Available at: <http://doi.org/10.5465/ amr.2011.0396>. Accessed on: Sept. 03, 2019.

COOPER, D.; THATCHER, S. M. B. Identification in organizations: the role of self-concept orientations and identification motives. Academy of Management Review, v. 35, n. 4, p. 516-538, 2010. Available at: <http://doi.org/10.5465/AMR.2010.53502693>. Accessed on: Sept. 03, 2019.
CULLINANE, N.; DONAGHEY, J. Employee silence. In: WILKINSON, A. et al. (Eds.). Handbook of research on employee voice. Cheltenham: Edward Elgar, 2014.

DETERT, J. R.; BURRIS, E. R. Leadership behavior and employee voice: is the door really open? Academy of Management Journal, v. 50, n. 4, p. 869-884, 2007. Available at: <http://doi.org/10.5465/ AMJ.2007.26279183>. Accessed on: Sept. 03, 2019.

DETERT, J. R.; EDMONDSON, A. C. Implicit voice theories: taken-forgranted rules of self-censorship at work. Academy of Management Journal, v. 54, n. 3, p. 461-488, 2011. Available at: <http://doi. org/10.5465/AMJ.2011.61967925>. Accessed on: Sept. 03, 2019.

DETERT, J. R.; TREVIÑO, L. K. Speaking up to higher-ups: how supervisors and skip-level leaders influence employee voice. Organization Science, v. 21, n. 1, p. 249-270, 2010. Available at: <http://doi.org/10.1287/ orsc.1080.0405>. Accessed on: Sept. 03, 2019.

DONAGHEY, J. et al. Reconceptualising employee silence: problems and prognosis. Work, Employment \& Society, v. 25, n. 1, p. 51-67, 2011. Available at: <http://doi.org/10.1177/0950017010389239>. Accessed on: Sept. 03, 2019.

DUTTON, J. E.; ASHFORD, S. J. Selling issues to top management. Academy of Management Review, v. 18, n. 3, p. 397-428, 1993. Available at: <http://doi.org/10.5465/AMR.1993.9309035145>. Accessed on: Sept. 03, 2019.

DUTTON, J. E. et al. Red light, greenlight: making sense of the organizational context for issue selling. Organization Science, v. 13, n. 4, p. 335-369, 2002. Available at: <http://doi.org/10.1287/ orsc.13.4.355.2949>. Accessed on: Sept. 03, 2019.

DUTTON, J. E.; ROBERTS, L. M.; BEDNAR, J. Pathways for positive identity construction at work: four types of positive identity and the building of social resources. Academy of Management Review, v. 35, n. 2, p. 265-293, 2010. Available at: <http://doi.org/10.5465/ AMR.2010.48463334>. Accessed on: Sept. 03, 2019.

FELIX, B.; CAVAZOTTE, F. When a calling goes unanswered: exploring the role of workplace personalizations as calling enactments. Frontiers in Psychology, v. 13, p. 1-14, 2019. Available at: <https:// doi.org/10.3389/fpsyg.2019.01940>. Accessed on: Sept. 03, 2019.

FELIX, B.; MELLO, A.; VON BORELL, D. Voices unspoken? Understanding how gay employees conconstruct a climate of voice/silence in organisations. The International Journal of Human Resource Management, v. 29, n. 5, p. 805-828, 2018. Available at: <http://doi. org/10.1080/09585192.2016.1255987>. Accessed on: Sept. 03, 2019.

FRAZIER, M. L.; FAINSHMIDT, S. Voice climate, work outcomes, and the mediating role of psychological empowerment: A multilevel examination. Group \& Organization Management, v. 37, n. 6, p. 691715, 2012. Available at: <http://doi.org/10.1177/1059601112463960>. Accessed on: Sept. 03, 2019.

GOMES, R.; FELIX, B.. O self no armário: uma teoria fundamentada sobre o silêncio de gays e de lésbicas no ambiente de trabalho. Cadernos EBAPE.BR, Rio de Janeiro, v. 17, n. 2, p. 375-388, 2019. Available at: <http://doi.org/10.1590/1679-395174796>. Accessed on: Sept. 03, 2019. 
GREENBERG, J.; EDWARDS, M. S. Voice and silence in organizations. Bingley: Emerald, 2009.

HARVEY, P.; MARTINKO, M. J.; DOUGLAS, S. C. Causal perceptions and the decision to speak up or pipe down. In: GREENBERG, J.; EDWARDS, M. S. (Eds.). Voice and silence in organizations. Bingley: Emerald, 2009.

HOGG, M. A.; TERRY, D. I. Social identity and self-categorization processes in organizational contexts. Academy of Management Review, v. 25, n. 1, p. 121-140, 2000. Available at: <http://doi.org/10.5465/ AMR.2000.2791606>. Accessed on: Sept. 03, 2019.

HOOD JUNIOR, R. et al. The psychology of religion: An empirical approach. New York: Guilford Press, 1996.

HOPTION, C.; CHRISTIE, A.; BARLING, J. Introduction. In: BARLING, J.; COOPER, C. (Eds.). Sage handbook of organizational behavior. London: Sage, 2008.

JANSSEN, O.; DE VRIES, T.; COZIJNSEN, A. J. Voicing by adapting and innovating employees: An empirical study on how personality and environment interact to affect voice behavior. Human Relations, v. 51, n. 7, p. 945-967, 1998.

KAUFMAN, B. E. Theorising determinants of employee voice: An integrative model across disciplines and levels of analysis. Human Resource Management Journal, v. 25, n. 1, p. 19-40, 2015. Available at: <http://doi.org/10.1111/1748-8583.12056>. Accessed on: Sept. 03, 2019.

KLAAS, B. S.; OLSON-BUCHANAN, J.; WARD, A.-K. The determinants of alternative forms of workplace voice: An integrative perspective. Journal of Management, v. 38, n. 1, p. 314-345, 2012. Available at: <http://doi.org/10.1177/0149206311423823>. Accessed on: Sept. 03, 2019.

KNOLL, M.; VAN DICK, R. Do I hear the whistle...? A first attempt to measure four forms of employee silence and their correlates. Journal of Business Ethics, v. 113, n. 2, p. 349-362, 2013. Available at: <http:// doi.org/10.1007/s10551-012-1308-4>. Accessed on: Sept. 03, 2019.

KREINER, G. E.; SHEEP, M. Growing pains and gains: Framing identity dynamics as opportunities for identity growth. In: ROBERTS, L. M.; DUTTON, J. E. (Eds.). Exploring positive identities and organizations: building a theoretical and research foundation. New York: Routledge, 2009.

LAM, C. F. et al. Shooting from the hip: a habit perspective of voice. Academy of Management Review, v. 43, n. 3, p. 470-486, 2018. Available at: <http://doi.org/10.5465/amr.2015.0366>. Accessed on: Sept. 03, 2019.

LEAVITT, K.; SLUSS, D. M. Lying for who we are: an identity-based model of workplace dishonesty. Academy of Management Review, v. 40, n. 4, p. 587-610, 2015. Available at: <http://doi.org/10.5465/ amr.2013.0167>. Accessed on: Sept. 03, 2019.

LEIKAS, S.; LINDEMAN, M. Personality, threat identification and emotional processing. European Journal of Personality, v. 23, n. 6, p. 455-474, 2009. Available at: <http://doi.org/10.1002/per.713>. Accessed on: Sept. 03, 2019.

LEPINE, J. A.; VAN DYNE, L. Voice and cooperative behavior as contrasting forms of contextual performance: evidence of differential relationships with big five personality characteristics and cognitive ability. Journal of Applied Psychology, v. 86. n. 2, p. 326-336, 2001. Available at: <http://doi.org/10.1037/0021-9010.86.2.326>. Accessed on: Sept. 03, 2019.

MARKUS, H.; WURF, E. The dynamic self-concept: a social psychological perspective. Annual Review of Psychology, v. 38, n. 1, p. 299-337, 1987. Available at: <http://doi.org/10.1146/annurev.ps.38.020187.001503>. Accessed on: Sept. 03, 2019.

MEAD, G. H. Mind, self and society. Chicago: University of Chicago Press, 1934.

MORRISON, E. W. Employee voice behavior: integration and directions for future research. Academy of Management Annals, v. 5, n. 1, p. 373-412, 2011.

MORRISON, E. W.; MILLIKEN, F. J. Organizational silence: a barrier to change and development in a pluralistic world. Academy of Management Review, v. 25, n. 4, p. 706-725. Available at: <http:// doi.org/10.5465/AMR.2000.3707697>. Accessed on: Sept. 03, 2019.

MORRISON, E. W.; WHEELER-SMITH, S. L.; KAMDAR, D. Speaking up in groups: A cross-level study of group voice climate and voice. Journal of Applied Psychology, v. 96, n. 1, p. 183-191, 2011. Available at: <http://doi.org/10.1037/a0020744>. Accessed on: Sept. 03, 2019.

MOWBRAY, P. K.; WILKINSON, A.; TSE, H. H. An integrative review of employee voice: identifying a common conceptualization and research agenda. International Journal of Management Reviews, v. 17, n. 3, p. 382-400, 2015. Available at: <http://doi.org/10.1111/ ijmr.12045>. Accessed on: Sept. 03, 2019.

NG, T. W. H.; FELDMAN, D. C. Employee voice behavior: a metaanalytic test of the conservation of resources framework. Journal of Organizational Behavior, v. 33, n. 2, p. 216-234, 2012. Available at: <http://doi.org/10.1002/job.754>. Accessed on: Sept. 03, 2019.

PETRIGLIERI, J. L. Under threat: responses to and the consequences of threats to individuals' identities. Academy of Management Review, v. 36, n. 4, p. 641-662, 2011. Available at: <http://doi.org/10.5465/ amr.2009.0087>. Accessed on: Sept. 03, 2019.

PINDER, C. C.; HARLOS, K. P. Employee silence: quiescence and acquiescence as responses to perceived injustice. Research in Personnel and Human Resources Management, v. 20, p. 331-369, 2001. Available at: <http://doi.org/10.1016/S0742-7301(01)20007-3>. Accessed on: Sept. 03, 2019.

PRATT, M. G.; FOREMAN, P. O. The Beauty of and Barriers to Organizational Theories of Identity. Academy of Management Review, v. 25 , n. 1, p. 141-152, 2000. Available at: <http://doi.org/10.5465/ AMR.2000.27711650>. Accessed on: Sept. 03, 2019.

SLUSS, D. M.; ASHFORTH, B. E. Relational identity and identification: Defining ourselves through work relationships. Academy of Management Review, v. 32, n. 1, p. 9-32, 2007. Available at: <http:// doi.org/10.5465/AMR.2007.23463672>. Accessed on: Sept. 03, 2019.

SMITH, C. A. The self, appraisal, and coping. In: SNYDER, C. R.; FORSYTH, D. R. (Eds.). Handbook of social and clinical psychology: the health perspective. Elmsford: Pergamon Press, 1991.

STAMPER, C. L.; VAN DYNE, L. Work status and organizational citizenship behavior: a field study of restaurant employees. Journal of Organizational Behavior, v. 22, n. 5, p. 517-536, 2001. Available at: <http://doi.org/10.1002/job.100>. Accessed on: Sept. 03, 2019. 
TANGIRALA, S.; RAMANUJAM, R. Exploring nonlinearity in employee voice: the effects of personal control and organizational identification. Academy of Management Journal, v. 51, n. 6, p. 1189-1203, 2008. Available at: <http://doi.org/10.5465/AMJ.2008.35732719>. Accessed on: Sept. 03, 2019.

VADERA, A. K.; AGUILERA, R. V.; CAZA, B. B. Making sense of whistleblowing's antecedents: Learning from research on identity and ethics programs. Business Ethics Quarterly, v. 19, n. 4, p. 553-586, 2009. Available at: <http://doi.org/10.5840/beq200919432>. Accessed on: Sept. 03, 2019.

VAN DYNE, L. V.; ANG, S.; BOTERO, I. C. Conceptualizing employee silence and employee voice as multidimensional constructs. Journal of Management Studies, v. 40, n. 6, p. 1359-1392, 2003. Available at: <http://doi.org/10.1111/1467-6486.00384>. Accessed on: Sept. 03, 2019.

VAN DYNE, L. V.; KAMDAR, D.; JOIREMAN, J. In-role perceptions buffer the negative impact of low $L M X$ on helping and enhance the positive impact of high LMX on voice. Journal of Applied Psychology, v. 93, n. 6, p. 1195-1207, 2008. Available at: <http://doi.org/10.1037/00219010.93.6.1195>. Accessed on: Sept. 03, 2019.
VROOM, V. H. Work and motivation. New York: Wiley, 1964.

WANG, Y. -D.; HSIEH, H.-H. Organizational ethical climate, perceived organizational support, and employee silence: A cross-level investigation. Human Relations, v. 66, n. 6, p. 783-802, 2013. Available at: <http://doi.org/10.1177/0018726712460706>. Accessed on: Sept. 03, 2019.

WEAVER, G. R.; AGLE, B. R. Religiosity and ethical behavior in organizations: A symbolic interactionist perspective. Academy of Management Review, v. 27, n. 1, p. 77-97, 2002. Available at: <http://doi.org/10.5465/AMR.2002.5922390>. Accessed on: Sept. 03, 2019.

WHITESIDE, D. B.; BARCLAY, L. J. Echoes of silence: Employee silence as a mediator between overall justice and employee outcomes. Journal of Business Ethics, v. 116, n. 2, p. 251-266, 2013. Available at: <http://doi.org/10.1007/s10551-012-1467-3>. Accessed on: Sept. 03, 2019.

WILKINSON, A.; FAY, C. New times for employee voice? Human Resource Management, v. 50, n. 1, p. 65-74, 2011. Available at: <http://doi.org/10.1002/hrm.20411>. Accessed on: Sept. 03, 2019.

Bruno Felix

ORCID: https://orcid.org/0000-0001-6183-009x

Ph.D. in Business Administration from Mackenzie Presbyterian University; Professor of the Graduate Program in Business Administration at Fucape Business School, Vitória-ES, Brazil. E-mail: bfelix@fucape.br 